\title{
CONCAR \\ APLIKASI COLOR TRACKER UNTUK KALKULATOR DENGAN MENGGUNAKAN AUGMENTED REALITY
}

\author{
Ali Mahmudi ${ }^{1}$, Ahmad Roziqi Zain ${ }^{2}$ \\ ${ }^{1}$ Teknik Informatika, Fakultas Teknologi Industri, Institut Teknologi Nasional Malang \\ amahmudi@hotmail.com ${ }^{1}$, zain.ahmadd@gmail.com ${ }^{2}$
}

\begin{abstract}
Penggunaan webcam Color Tracker dengan pengaturan awal warna marker berwarna Merah, Biru atau Hijau, digunakan untuk mengerakkan kursor di komputer. Bila terjadi tumbukan antara kursor dengan salah satu tombol concar maka akan menampilkan sebuah angka. Pergerakan kursor terjadi dengan mengambil titik koordinat $X$ dan $Y$ dari pencarian nilai titik-titik pixel yang sama dengan nilai pengaturan Marker awal. Jangkauan webcam berukuran $800 x 600$ pixel dengan tampilan Mirror.
\end{abstract}

Setelah dilakukan proses pengujian yang dilakukan terhadap 17 orang dengan mengisi kuisioner mendapatkan presentase tingkat keberhasilan 91,5\%. Sistem operasi yang dapat digunakan oleh aplikasi ini adalah Windows.

Keywords : Webcam, Augmented Reality, Color Tracker, Kalkulator.

\section{PENDAHULUAN}

Mengontrol sebuah aplikasi komputer tanpa menyentuh perangkat keras komputer, dengan menggunakan media inputan webcam, merupakan hal yang relatif baru. Sebuah video yang diambil dari webcam, kemudian diproses setiap pixel-nya, sedemikian hingga dapat menggerakkan kursor dan memasukkan angka ke dalam komputer secara langsung.

Analisis dari perusahaan Juniper Research di Amerika memperkirakan Augmented reality (AR) akan memberikan pendapatan sebesar 732 juta dollar selambatlambatnya tahun 2014. Teknologi dengan menggunakan pendekatan Augmented Reality, sudah banyak digunakan di Indonesia, antara lain oleh Kompas, Sosro, LA Light, MetroTV hingga berkembang pada digital televisi yaitu SmartTV.

\section{LANDASAN TEORI}

\subsection{Augmented Reality}

Augmented Reality (AR) adalah sebuah pencitraan 2 atau 3 dimensi yang diproyeksikan kedalam waktu nyata. Pengguna akan merasa melihat 2 atau 3 dimensi tersebut dalam layar dengan sebuah marker.

Augmented Reality terbagi dalam empat tipe ${ }^{[5]}$, yaitu :

1. Marker, bersifat single, multi, paddle marker. Contoh QRcode dan Barcode.
2. Natural Feature (Markerless), bersifat single, multi object. Contoh Face Recognition, Motion Detection.

3. Grafmetric, bersifat Position Coordinate, Compass. Contoh Wikitude.

4. Visual Search, bersifat Single, replacement. Contoh Translating OCR.

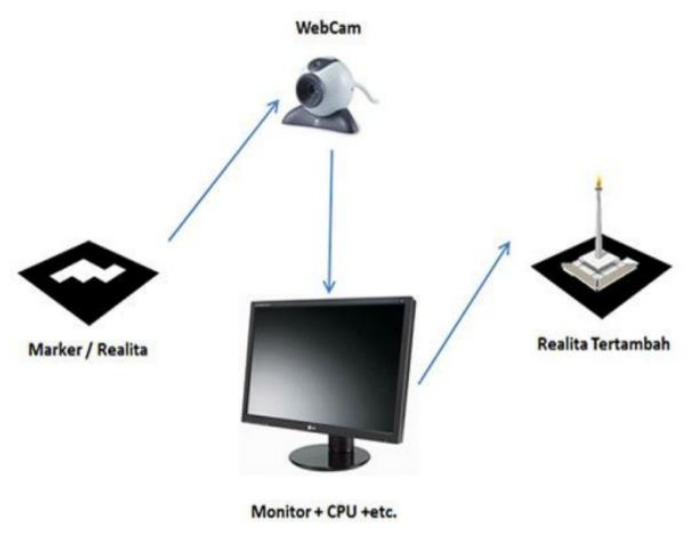

Gambar 1. Secara umum AR

\subsection{Threshold}

Untuk warna-warna dasar nilai RGB cukup efektif dalam melakukan deteksi. Nilai threshold dapat diambil berdasarkan pola warna, tetapi sangat rentan terhadap kestabilan cahaya. Penggunaan threshold dengan menggunakan rumus seperti pada persamaan 1 . 


$$
f(x, y)^{\prime}=\left\{\begin{array}{l}
a 1, f(x, y)<T \\
a 2, f(x, y) \geq T
\end{array}\right.
$$

\subsection{Adobe Flash CS5}

Adobe Flash merupakan sebuah aplikasi yang dibuat oleh Adobe dan program standar authoring tool professional. Adobe Flash digunakan untuk membuat animasi dan Gambar yang sangat menarik. Apliasi ini juga digunakan untuk membuat situs web sehingga situs menjadi lebih interaktif dan dinamis Selain itu, Adobe Flash juga dapat digunakan untuk membuat animasi logo, movie, game, navigasi pada situs web, tombol animasi, banner, dan screen saver.

Adobe Flash memiliki fasilitas-fasilitas pembantu untuk membuat animasi, yaitu fasilitas Action Script, filter, custom easing, dan dapat memasukkan video lengkap dengan fasilitas playback FLV. Keunggulan yang dimiliki Adobe Flash adalah mampu menerima script pemrograman, baik yang berjalan sendiri atau digunakan bersama-sama dengan XML, PHP, dan Database.

\subsection{Action Script 3.0}

Action Script 3.0 (AS3) merupakan bahasa pemrograman yang bekerja didalam platform Adobe Flash. Action Script dibangun untuk mengembangkan pemrograman interaktif secara efisien. Platform aplikasi Flash Action Script dapat digunakan untuk membuat animasi yang sederhana sampai dengan yang kompleks. Penggunaan data dan aplikasi tampilan yang interaktif, pertama kali diperkenalkan dalam Flash Player 9.

Acrion Script merupakan bahasa pemrograman berorientasi objek didasarkan pada ECMA Script-standar yang menjadi dasar JavaScript dan memberikan hasil yang luar biasa dalam kinerja dan produktifitas pengembang.

\subsection{Dynamic Text}

Merupakan bentuk teks yang isinya bisa berubah sesuai dengan proses tertentu. Dynamic text berbeda dengan static text karena isi dari static text tidak dapat berubah-ubah atau tetap ${ }^{[1]}$. Dynamic text dipakai dalam pembuatan animasi atau game. Aplikasi ini dapat diimplementasikan pada hasil nilai yang selalu berubah menurut kaidah waktu atau proses tertentu sehingga nilai tersebut mempunyai arti tertentu.

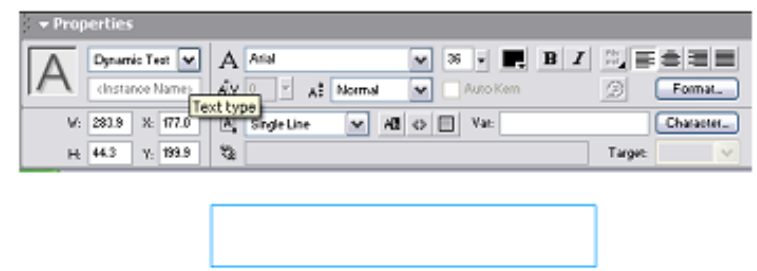

Gambar 2. Pembuatan Dynamic Text

\subsection{Motion Tween}

Motion Tween adalah sebuah aplikasi untuk pembuatan animasi dengan mengubah ukuran, rotasi, atau posisi yang dilakukan secara terus menerus dalam jangka waktu tertentu.

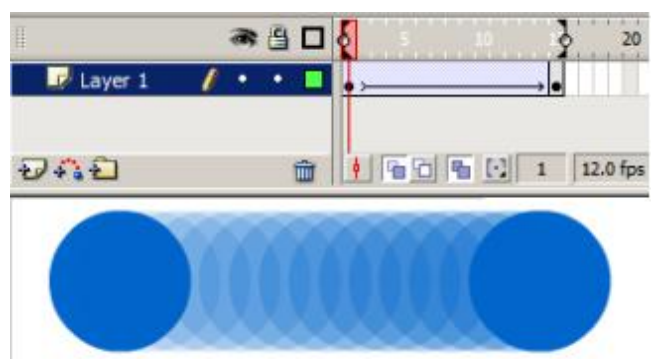

Gambar 3 Motion Tween.

\subsection{Deteksi Tumbukan}

Tumbukan terjadi jika dua movie clip yang saling bersentuhan. Hal ini dapat diimplementasikan ketika terdapat objek yang saling bersentuhan, maka akan melakukan sebuah proses tertentu.

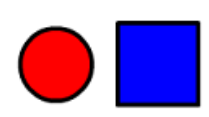

tumbukan belum terjadi

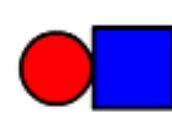

tumbukan sudah terjadi

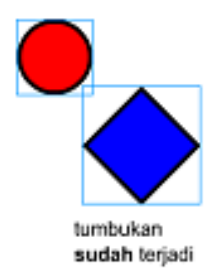

sudah teriadi
Gambar 4. Pendeteksian Tumbukan Objek

Pada Gambar ketiga dari Gambar 4, menurut mata kita, movie clip lingkaran dengan movie clip kotak belum terjadi tumbukan. Tetapi dalam flash, tumbukan tersebut sudah terjadi karena tumbukan dihitung dari sebuah bentuk kotak yang dibentuk oleh garis-garis yang ditarik dari titik terluar sebuah movie clip ${ }^{[4]}$. 


\section{PERANCANGAN DAN ANALISIS}

\subsection{Analisa Kebutuhan}

Perancangan Concar ini menggunakan beberapa proses pengolahan citra, salah satunya yaitu Color Tracker. Diagram blok perencanaan perangkat lunak terdapat pada Gambar 5.

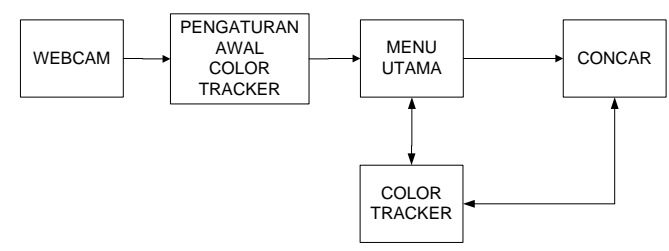

Gambar 5. Diagram Blok Perancangan

Spesifikasi perangkat lunak yang digunakan dalam pembuatan aplikasi ini adalah

1. Adobe Flash CS5

2. FlashDevelop-4.3.0-RTM

3. SDK FLEX 4.6

Aplikasi yang dibuat meliputi pembacaan webcam untuk menerima inputan dari warna marker merah, biru ataupun hijau. Tampilan mirror untuk memudahkan kontrol. Tampilan mirror ini dibuat dengan video webcam yang kemudian diolah per pixel. Hal ini disebut dengan Color Tracker. Color Tracker ini untuk mengendalikan dan menjalankan kursor dengan mengikuti warna tertentu yang dibaca oleh webcam.

\subsection{Color Tracker}

Sebelum menggunakan Color Tracker, hal yang perlu dilakukan adalah pengaturan warna awal yang untuk mengontrol kursor. Hal ini dilakukan karena jangkauan yang dideteksi oleh webcam berukuran 800x600 pixel. Jika terdapat titik warna dengan nilai pixel yang sama, maka kursor akan mengikuti posisi marker pada jari tangan. Penggunaan Color Tracker dengan memasang marker berwarna merah, biru, atau hijau pada salah satu jari tangan, ditunjukkan pada Gambar 6. Cara pembacaan warna marker dengan melakukan pencarian nilai titik yang sesuai dengan nilai awal aplikasi, hal tersebut disebut dengan kursor $^{[7]}$.

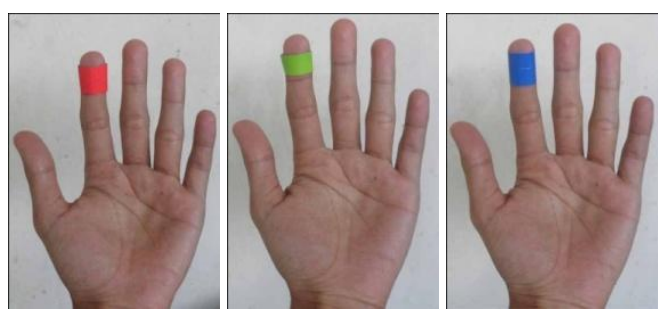

Gambar 6. Marker Warna Pada Jari Tangan

Color Tracker terbagi menjadi beberapa proses yang saling berhubungan. Salah satu proses di dalam color tracker adalah cek warna pixel. Cek warna pixel adalah proses penyesuaian nilai pixel saat pengaturan awal dengan nilai marker yang ditangkap oleh webcam. Proses Color Tracker ditunjukkan pada Gambar 7.

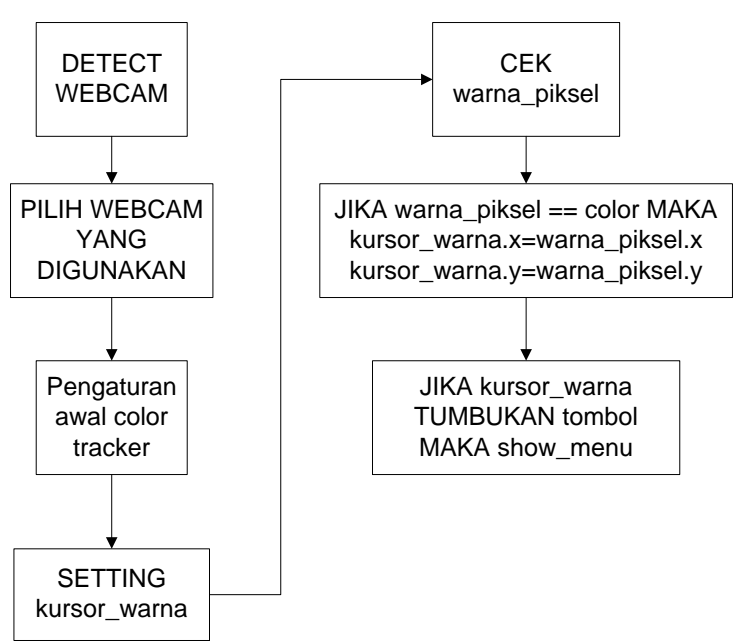

Gambar 7. Diagram Blok Color Tracker

\subsection{Struktur Navigasi}

Agar memiliki menu yang jelas, maka dibuat struktur navigasi seperti ditunjukkan pada Gambar 8 .

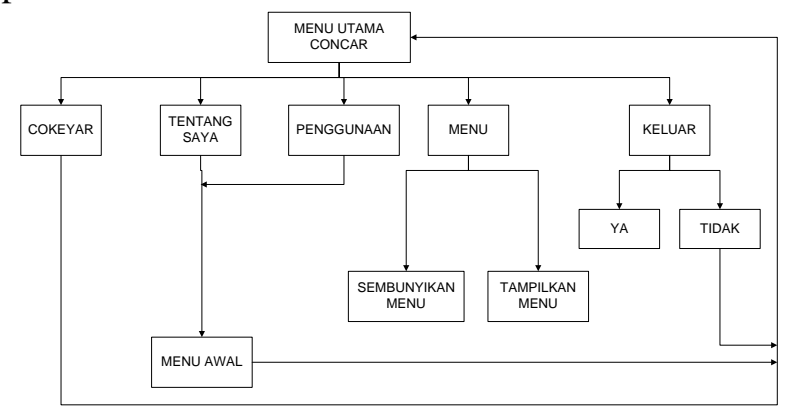

Gambar 8. Struktur Navigasi Concar 


\section{PEMBAHASAN DAN HASIL}

\subsection{Implementasi Augmented Reality}

Pada bagian implementasi ini yang dilakukan yaitu proses pembacaan warna sebagai acuan pengganti kursor (Color Tracker). Color tracker digunakan untuk memilih menu dengan acuan warna merah, hijau atau biru yang dipasang pada salah satu jari tangan.

\subsection{Pembacaan Kursor Marker}

Pengaturan awal warna kursor dapat diatur sebelum melakukan pemilihan menu. Pengaturan awal warna kursor dilakukan dengan meng-klik warna marker pada posisi yang sejajar. Pada proses ini, dilakukan pengambilan warna dan kemudian disimpan sementara sebagai indikator kursor. Pendeteksian warna dilakukan setiap 30 FPS pada setiap pixel dengan ukuran Gambar 800x600 pixel. Pencocokan nilai warna dilakukan secara heksadesimal.

Setelah melakukan pengaturan awal warna marker merah, biru atau hijau, langkah selanjutnya adalah melakukan pemilihan menu utama dengan menyentuhkan bagian marker warna ke jangkauan tombol menu utama. Bila Color Tracker berhasil mendeteksi warna dan melakukan tumbukan atau pilihan, maka halaman selanjutnya akan menampilkan halaman animasi Motion Tween yang berisi informasi, cara penggunaan, konfirmasi keluar dari aplikasi permainan dan menyembunyikan menu sementara. Pada Gambar 9 dilakukan percobaan pemilihan salah satu menu, yang bertumbukan dengan kursor sehingga akan menampilkan sebuah halaman dengan animasi Motion Tween.

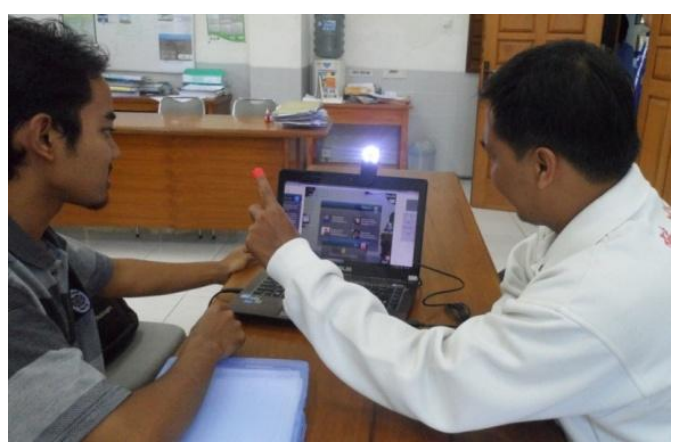

Gambar 9. Percobaan Color Tracker Menu Utama

\subsection{Halaman Concar}

Halaman Concar akan muncul bila terjadi tumbukan antara Color Tracker dengan tombol menu Concar yang terletak pada kanan-atas.

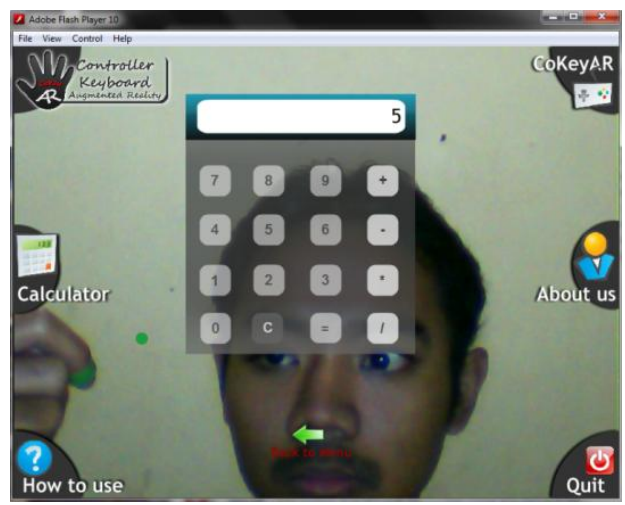

Gambar 10. Halaman Concar

Setelah Concar selesai maka dilakukan pengembangan yaitu membuat Calculator Augmented Reality, tampilan aplikasi tersebut pada Gambar 10.

\subsection{Halaman Tentang Kami}

Halaman tentang kami, seperti ditunjukkan pada Gambar 11, berisi informasi tentang aplikasi ini. Seperti pembuat, judul, metode yang digunakan, logo, nama program studi dan kampus tempat dimana proses pembuatan. Tombol Back to Menu dapat digunakan untuk kembali ke menu utama.

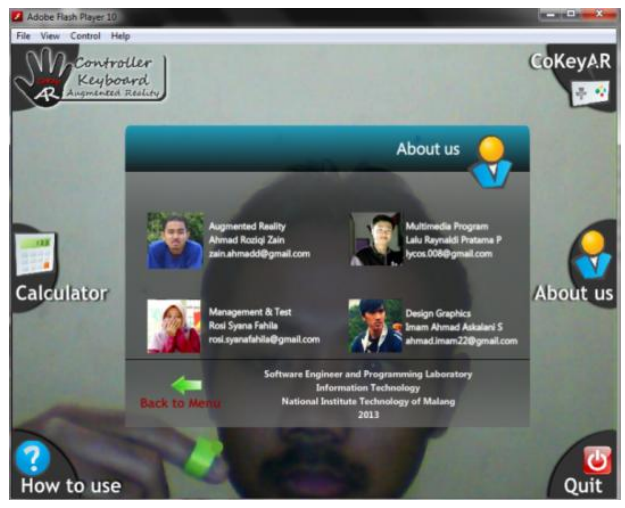

Gambar 11. Halaman Tentang Saya

\subsection{Halaman Penggunaan}

Halaman Penggunaan, seperti ditunjukkan pada halaman 12 , berisi tata cara menggunakan aplikasi ini. Hal tersebut dijelaskan pada halaman How to Use. Untuk memilih halaman ini, dengan melakukan tumbukan pada tombol How to Use yang tersedia pada layar menu utama yang telah disediakan. Cara mengembalikan ke posisi halaman semula, 
dengan melakukan tumbukan pada Gambar animasi tombol Back to Menu. Kemudian, tampilan kembali ke halaman utama dengan menu utama.

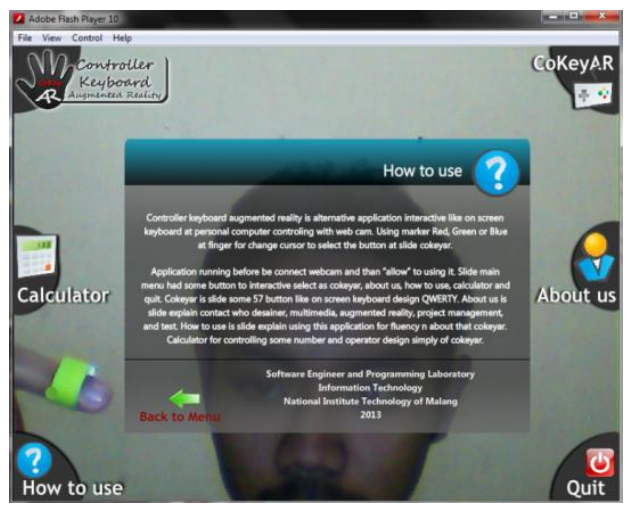

Gambar 12. Halaman Penggunaan

\subsection{Halaman Konfirmasi Keluar}

Pada Gambar 13 berisi tampilan halaman konfirmasi Keluar yaitu sebuah halaman konfirmasi untuk keluar atau tidak dari aplikasi Concar ini. Hal ini dilakukan dengan memilih TIDAK untuk membatalkan proses keluar dari aplikasi Concar atau pilih YA untuk tetap menggunakan aplikasi Concar.

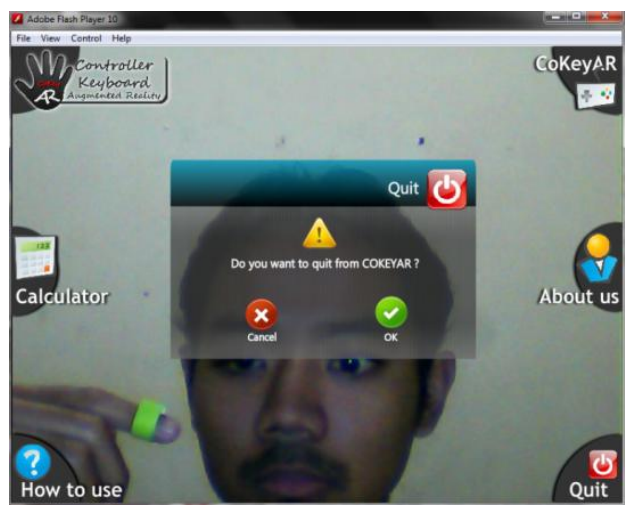

Gambar 13. Halaman konfirmasi keluar dari Concar

\subsection{Pengujian}

Pengujian dilakukan dengan mengisi kuisioner. Pemilihan penguji aplikasi dipilih secara acak yang berjumlah 17 orang dengan 9 pertanyaan pada setiap lembar kuisioner. Tabel 1 merupakan tabulasi hasil pengujian White Box, Tabel 2 merupakan pengujian efektifitas, Tabel 3 merupakan pengujian desain tampilan, dan Tabel 4 merupakan pengujian kemudahan.
Tabel 1. Pengujian Kebutuhan Fungsional

\begin{tabular}{|l|l|l|l|}
\hline \multirow{2}{*}{ No } & \multirow{2}{*}{ Fungsi } & \multicolumn{2}{|l|}{ Persentase } \\
\cline { 3 - 4 } 1 & $\begin{array}{l}\text { Pemilihan webcam } \\
\text { yang digunakan }\end{array}$ & $100 \%$ & $0 \%$ \\
\hline 2 & $\begin{array}{l}\text { Pengaturan awal } \\
\text { warna dari color } \\
\text { tracker }\end{array}$ & $76.4 \%$ & $23.5 \%$ \\
\hline 3 & $\begin{array}{l}\text { Jika terjadi tumbukan } \\
\text { antara kursor dengan } \\
\text { salah satu menu, akan } \\
\text { menampilkan isi } \\
\text { menu }\end{array}$ & $82.3 \%$ & $17.6 \%$ \\
\hline 4 & $\begin{array}{l}\text { Menyembunyikan } \\
\text { menu utama }\end{array}$ & $82.3 \%$ & $17.6 \%$ \\
\hline 5 & $\begin{array}{l}\text { Menampilkan menu } \\
\text { utama }\end{array}$ & $94.1 \%$ & $5.8 \%$ \\
\hline
\end{tabular}

Tabel 2. Pengujian Efektifitas

\begin{tabular}{|l|l|l|l|}
\hline No & Kategori & Jumlah & Persentase \\
\hline 1 & Efektif & 5 & $29.4 \%$ \\
\hline 2 & $\begin{array}{l}\text { Cukup } \\
\text { efektif }\end{array}$ & 10 & $58.8 \%$ \\
\hline 3 & $\begin{array}{l}\text { Kurang } \\
\text { efektif }\end{array}$ & 2 & $11.7 \%$ \\
\hline
\end{tabular}

Tabel 3. Pengujian Desain Tampilan

\begin{tabular}{|l|l|l|l|}
\hline No & Kategori & Jumlah & Persentase \\
\hline 1 & Baik & 9 & $52.9 \%$ \\
\hline 2 & $\begin{array}{l}\text { Cukup } \\
\text { Baik }\end{array}$ & 7 & $41.1 \%$ \\
\hline 3 & $\begin{array}{l}\text { Kurang } \\
\text { Baik }\end{array}$ & 1 & $5.8 \%$ \\
\hline
\end{tabular}

Tabel 4. Pengujian Kemudahan

\begin{tabular}{|l|l|l|l|}
\hline No & Kategori & Jumlah & Persentase \\
\hline 1 & Mudah & 6 & $35.2 \%$ \\
\hline 2 & $\begin{array}{l}\text { Cukup } \\
\text { Mudah }\end{array}$ & 8 & $47 \%$ \\
\hline 3 & $\begin{array}{l}\text { Kurang } \\
\text { Mudah }\end{array}$ & 3 & $17.6 \%$ \\
\hline
\end{tabular}

\subsection{Kelebihan dan Kekurangan Color Tracker}

Kelebihan dari Concar ini ialah aplikasi ini dapat memilih menu dengan Color Tracker. Color Tracker adalah sebuah jari yang diberi marker warna merah, biru, atau hijau dengan pengaturan awal terlebih dahulu. Dengan adanya Color Tracker gerakan tangan pada jangkauan tertentu, pengguna tidak perlu menyentuh keyboard.

Color Tracker memiliki kekurangan yaitu saat kursor tidak dapat mengikuti warna 
merah, biru atau hijau. Hal tersebut dapat terjadi bila warna yang terdapat pada jari terlalu cerah atau terlalu redup. Sehingga harus menggunakan webcam yang disertai dengan cahaya LED.

\section{PENUTUP}

\subsection{Kesimpulan}

1. Color Tracker dapat digunakan untuk memilih menu utama dengan menggerakkan jari yang dipasangi warna merah, biru atau hijau, yang diatur terlebih dahulu di awal pemakaian aplikasi.

2. Color Tracker dapat digunakan dengan baik jika penyinaran cahaya tidak berubah. Sehingga, kursor dapat mengikuti warna dengan baik. Selain itu, Color Tracker dapat digunakan dengan baik jika warna marker yang digunakan sebagai kursor hanya ada 1 warna pada layar yang dideteksi.

3. Implementasi ini diujikan pada penggunap acak yg berjumlah 17 orang dengan mengisi kuisioner yang berisi 17 pertanyaan, dan mendapatkan presentase tingkat keberhasilannya $91.5 \%$ dan tingkat kegagalan $8.5 \%$.

4. Pada pengujian efektifitas, diperoleh hasil Cukup Efektif dengan presentase $58.8 \%$, pengujian desain tampilan mendapatkan hasil Baik dengan presentase $52.9 \%$, pengujian kemudahan mendapatkan hasil Cukup Mudah dengan presentase $47 \%$.

5. Aplikasi ini dijalankan dengan menggunakan sistem operasi Windows. Pada sistem operasi Linux (Ubuntu), Macintos masih belum bisa dijalankan karena tidak dapat membaca driver webcam.

\subsection{Saran}

1. Color Tracker yang masih menggunakan marker berwarna merah, biru atau hijau yang dipasang pada jari dapat digantikan dengan Hand-Tracking sehingga untuk menggerakkan kursor dapat lebih efektif dan mudah digunakan.

2. Bentuk desain dapat dikembangkan dengan bentuk animasi 3 dimensi.

3. Kepekaan pada Motion Detector dapat ditingkatkan dengan menggabungkan teknologi Kinect, 3GearSystem, atau Motion Leap, sehingga dapat mengenali bentuk tangan lebih detail, seperti ibu jari, jari telunjuk jari tengah, jari manis, ataupun kelingking.

4. Aplikasi ini dapat dikembangkan sehingga dapat dijalankan dengan menggunakan sistem operasi Linux, Mahintosh.

\section{DAFTAR PUSTAKA}

[1] Dhewiberta H. 2009. Mahir dalam 7 Hari : Macromedia Flash MX 2004. Yogyakarta : Andi Offset.

[2] Fadlisyah,S.Si. 2007. Computer Vision dan Pengolahan Citra.Yogyakarta : CV.Andi Offset.

[3] Radion, K S.ST. 2012. Easy Game Programming Using Flash and ActionScript 3.0. Yogyakarta : CV.Andi Offset.

[4] Zeembry. 2005. 123 Tip \& Trik Action Script Flash MX 2004.Jakarta : PT Elex Media Komputindo.

[5] Madden, L. 2011. Professional Augmented Reality, Browser for Smartphones.Wiley Publishing,Inc.

[6] Shupe, R and Z.R. 2011. Learning Action Script 3.0 Second Edition.O'Reilly Media,Inc.

[7] Braunstein,R and M.H.W. 2008. Action Script 3.0 Bible. Wiley Publishing,Inc.

[8] $\longrightarrow$ Teknologi Augmented Reality, sumber http://www.scribd.com/doc/55994631/Tek nologi-Augmented-Reality. Diakses tanggal 8 Maret 2013 pukul 03:01.

[9] _ Augmented Reality Masa Depan Interaktifitas, sumber: http://teknologiterkini.com/augmentedreality-masa-depan-interaktivitas/.

Diakses tanggal 2 April 2012 pukul 11:10. [10]

Berbasis Augmented Reality, sumber : http://www.selular.co.id/berita/BNews/20 11/02/192/Pendapatan-Layanan Berbasis-Augmented-Reality-Mencapai\$15-Miliar-di-2015.htm. Diakses tanggal 17 Mei 2013 pukul 19:22. 